Article

\title{
A Systemic Approach for Sustainability Implementation Planning at the Local Level by SDG Target Prioritization: The Case of Quebec City
}

\author{
David Tremblay ${ }^{1, *} \mathbb{1}$, Sabine Gowsy ${ }^{2}$, Olivier Riffon ${ }^{1}$, Jean-François Boucher ${ }^{1} \mathbb{D}$, Samuel Dubé ${ }^{2}$ \\ and Claude Villeneuve ${ }^{1}$ \\ 1 Département des Sciences Fondamentales, Université du Québec à Chicoutimi, Chicoutimi, \\ QC G7H 2B1, Canada; olivier_riffon@uqac.ca (O.R.); jean-francois_boucher@uqac.ca (J.-F.B.); \\ claude_villeneuve@uqac.ca (C.V.) \\ 2 Ville de Québec, Québec, QC G1R 4A2, Canada; Sabine.Gowsy@ville.quebec.qc.ca (S.G.); \\ Samuel.Dube@ville.quebec.qc.ca (S.D.) \\ * Correspondence: david1_tremblay@uqac.ca
}

Citation: Tremblay, D.; Gowsy, S.; Riffon, O.; Boucher, J.-F.; Dubé, S.; Villeneuve, C. A Systemic Approach for Sustainability Implementation Planning at the Local Level by SDG Target Prioritization: The Case of Quebec City. Sustainability 2021, 13, 2520. https://doi.org/10.3390/su 13052520

Academic Editors:

Margarita Martinez-Nuñez and Ma Pilar Latorre-Martínez

Received: 23 January 2021

Accepted: 22 February 2021

Published: 26 February 2021

Publisher's Note: MDPI stays neutral with regard to jurisdictional claims in published maps and institutional affiliations.

Copyright: (c) 2021 by the authors. Licensee MDPI, Basel, Switzerland. This article is an open access article distributed under the terms and conditions of the Creative Commons Attribution (CC BY) license (https:// creativecommons.org/licenses/by/ $4.0 /)$.

\begin{abstract}
The success of the 2030 Agenda hinges on mobilization at the local level. The localization of sustainable development goals (SDGs) and their targets involves adapting them to local contexts. This case study of Quebec City, Canada, illustrates how the use of a systemic sustainability analysis tool can help integrate SDGs in the building of a sustainable development strategy at the local level. Our approach focuses on the use of an SDG target prioritization grid (SDGT-PG) and begins with the mobilization and training of a group of officers representing various city services. We first used an original text-mining framework to evaluate SDG integration within existing strategic documents published by the city. The result provides a portrait of existing contributions to SDG targets and identifies potential synergies and trade-offs between services and existing policies. A citywide prioritization workshop was held to assess the relative importance of SDG targets for the city. Priorities were then identified by combining the importance of the targets as viewed by stakeholders, the current level of achievement of SDG targets as determined by the analysis of existing documents, and the jurisdiction and responsibilities given to Quebec City in regard to federal and provincial legislation. We identified the main focus areas and related SDG targets. Furthermore, we observed whether actions needed to be consolidated or new actions needed to be implemented. The identification of synergies and trade-offs within the city service actions provides information on the links to be made between the different municipal services and calls for partnerships with other organizations. The use of the SDGT-PG allows the vertical and horizontal integration of the SDG targets and demonstrates how participation and inclusion facilitate stakeholders' appropriation of the applied sustainable development strategy.
\end{abstract}

Keywords: 2030 Agenda; sustainable development goals (SDGs); systemic sustainability analysis; SDG targets prioritization

\section{Introduction}

In 2015, members of the United Nations unanimously adopted the 2030 Agenda for Sustainable Development [1]. The 17 Sustainable Development Goals (SDG) and 169 targets represent a global framework to guide the implementation of sustainable development (SD) by 2030 [2,3]. While the SDGs and targets were first designed for the global level [4], the 2030 Agenda is a universal program that applies to all governments and actors, regardless of their level of intervention [1,5]. Because cities represent the level of government closest to the population [6], they have the capacity to intervene quickly and concretely, according to the powers assigned to them, [7-9], and they are considered essential actors for sustainability [4]. Furthermore, urbanization is accelerating globally, 
and 68 percent of the world's population is expected to live in an urban area by 2050 [10]. Moreover, all human activities at the city level affect the economy, the environment, people, culture, governance, etc. [4,8,9,11-13].

Implementing the 2030 Agenda and achieving the SDGs require an integrated and systemic approach $[1,14,15]$. The principle of integration applies (i) horizontally between different policy areas, (ii) vertically from global to national to local levels, and (iii) territorially between local governments [6]. SDG implementation at the local level is termed "localization". In the context of implementing the 2030 Agenda, SDG localization refers to "the process of defining, implementing, and monitoring strategies at the local level for achieving global, national, and subnational SDGs and targets" [16]. Although there are numerous approaches and tools at the national level [11], the localization of SDGs requires documented [3] approaches adapted to applying sustainable development at the local level [17]. Scientific research on cities and the SDGs has increased [7,18,19]; nonetheless, there remains a knowledge gap in regard to how best to implement SDGs at the local level $[3,11]$.

Approaches and tools dedicated to SDG localization involve some critical elements. Although the 17 SDGs and their 169 targets are set as "universal and indivisible," they must be applied in line with the realities, capacities, levels of development, and priorities specific to national or local contexts $[1,20]$. Cities face various challenges when implementing SDGs. These challenges include contextualizing their approaches to the specific environmental, economic, social, political, and cultural conditions [7,21,22]. This contextualization involves adapting SDG content and their targets to make them locally relevant $[3,6]$ while maintaining integrated and systemic thinking to keep a holistic perspective of the system as a whole $[1,14,15,23]$. The systemic approach implies horizontal, vertical, and territorial integration [24]. Horizontally, integration aims to maximize synergies and diminish trade-offs [4,24-27]. Vertically, at the local level, integration involves the principle of subsidiarity $[7,11,28]$ and a clear understanding of the division of powers between the various levels of government $[11,14,28]$. In addition to implementing SDGs, invoking these elements will ensure policy coherence and integrated multilevel governance [6,7,28].

The issue of prioritizing SDG targets is critical for local authorities, as the needs are multiple and urgent; yet, there are often limited capacities and resources. Prioritization is a complex exercise that combines assessing the importance of a target and determining its level of achievement at a specific time, for a given territory [2]. The integrated approach of the SDGs induces a paradigm shift in the elaboration of development plans and strategies at all levels. Today, it is a matter of contributing to the achievement of a global and shared vision. Thus, SDGs and their targets may constitute a normative framework. Given the inability and, most likely, the irrelevancy for cities to implement all the targets, it is essential to use approaches and tools to determine priorities [4,29].

A growing number of studies are looking at a systemic approach for prioritizing and implementing the SDGs [12,27,30,31]; however, very few tools for SDG and target prioritization are documented in the scientific literature. Among papers presenting tools, three include a set of criteria for establishing priorities. First, Allen et al. [30] proposed a multicriteria analysis for prioritizing SDG targets through the use of three main criteria:

1. Level of urgency: identifying historical trends and comparing current baseline values against global benchmarks;

2. Systemic impact: identifying interlinkages between SDG targets, evaluated against a semi-quantitative cross-impact matrix assessment and network analysis;

3. Policy gap: assessing how SDGs align with existing strategies.

The Stakeholder Forum [20] submitted a method of analysis addressed to developed countries to assist them in identifying the goals and targets representing the biggest transformational challenges. They proposed three criteria:

1. Applicability: evaluating the relevance of the goal/target;

2. Implementability: assessing the reality of attaining the goal/target within the time frame; 
3. Transformationalism: determining whether the achievement of the goal/target requires new and additional policies beyond those currently in place.

Finally, the Sustainable Development Solution Network (SDSN) [6] proposed broad guidelines to define local SDG targets:

1. Targets should be relevant and achievable;

2. Targets should correspond to local government mandates;

3. Priorities should be established on the basis of development gaps.

This paper presents the case study of Quebec City (Quebec, Canada) using an original and adapted systemic sustainability analysis tool. Quebec City is located in the province of Quebec, Canada. Canada is a federal state where responsibilities are shared between federal and provincial jurisdictions. Local governments, such as cities, are a provincial responsibility; however, as issues related to sustainable development touch multiple jurisdictions, our analysis includes the federal, provincial, and local (city) levels. This approach aims to bolster the implementation of the SDGs at the local level and integrates the key elements of contextualization, adaptation, systemic thinking, subsidiarity, and policy coherence.

The method focuses mainly on the use of the SDG target prioritization grid (SDGT-PG), a participatory prioritization tool for SDG targets applicable at local, national, and regional scales. The SDGT-PG methodology is inspired by the sustainable development analytical grid (SDAG) used at local and national levels since 1988 [32]. The SDAG methodology, which emphasizes participatory processes and scientific robustness, was developed in a partnership between academics (Université du Québec à Chicoutimi, Canada), an international organization (Organisation internationale de la Francophonie), and an international consulting firm (GlobalShift Institute Ltd., Quebec City, QC, Canada). This approach was tested in both developed and developing countries at national and local levels. Burkina Faso, Benin, Niger, and Togo refer to the use of the SDGT-PG as a prioritization tool in their Voluntary National Reviews presented at the United Nations High-level Political Forum on Sustainable Development. In this study, we test our central hypothesis that the use of the SDGT-PG allows the vertical and horizontal integration of the SDG targets. We also demonstrate how participation and inclusion permit stakeholder appropriation.

\section{Materials and Methods}

The applied approach is an iterative process (Figure 1) inspired by two analytical tools: the sustainable development analytical grid (SDAG) [32] and the rapid integrated assessment (RIA) [33]. Our approach also makes use of best-known practices and guidelines $[6,20,30]$. The different advancements of this action-research process, in coconstruction with Quebec City officials, aimed to generate data and information related to the three main SDGT-PG criteria being evaluated:

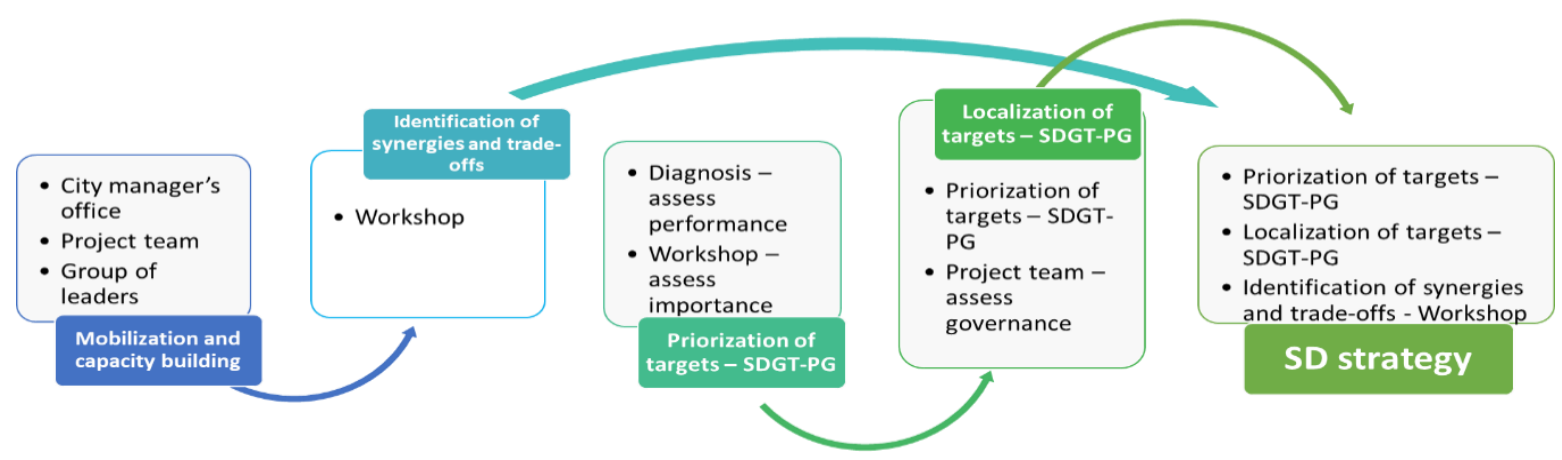

Figure 1. Stages of the applied approach.

1. Performance: Relying on SDG target indicators, what is the current level of achievement of the targets? 
2. Importance: Given the specific context of the city, what is the significance level of the targets?

3. Governance: Knowing the constitutional division of powers, what level of governance (from national to local) holds the power and responsibilities associated with the targets?

\subsection{Mobilization and Capacity Building}

To eliminate silos and apply a systemic approach, we took the initial step of forming a group of leaders. We mobilized 27 leaders from 19 Quebec City's administrative units. To be selected, a leader needed to represent one of the main administrative units and embody the concepts of sustainability through their values, interests, personal, and/or professional activities. The selected leaders were readily available and also had the authorization of their respective managers. The 27 leaders included 17 advisers, 6 managers, 2 engineers, 1 analyst, and 1 police officer. The leaders comprised 15 men and 12 women. The city manager's office coordinated the project. The project team, established by the office, worked in partnership with our research team to organize and structure the complete process.

A series of workshops was co-managed by the partners. The main objective of these workshops was to raise awareness about the SDGs [6]. The specific objectives were to:

1. Understand the concepts of sustainable development;

2. Become familiar with the 2030 Agenda and the SDGs;

3. Understand systemic sustainability analysis;

4. Share practices between city services;

5. Identify potential synergies and trade-offs;

6. Prepare the prioritization activity;

7. Produce and validate proposals for the sustainable development strategy.

\subsection{Diagnosis-Performance}

The internalization of the SDGs requires identifying those already-existing actions that can be linked to the SDGs $[6,14]$. To carry out this diagnosis, we analyzed 89 strategic documents produced by Quebec City (A list of the analyzed documents is available in the Supplementary Materials). We aimed to:

1. Identify already-implemented SD initiatives;

2. Align the identified SD initiatives with SDG targets;

3. Assess the potential achievement of the SDG targets (document the performance criteria of the SDGT-PG).

We identified the initiatives using WordStat, a content-analysis and text-mining software within ProSuite (Provalis Research, Montreal, QC, Canada), a collection of integrated text-analysis tools [34]. For our analyses, we developed a specific dictionary linked to the content of the 2030 Agenda. Our dictionary included 1602 expressions found in the labels of the SDGs, SDG targets, and SDG indicators (The full dictionary is available in the Supplementary Materials).

First, we prepared each document for analysis by removing figures, hyphens, brackets, and braces. We imported the strategic documents into QDA Miner, a qualitative data analysis component of ProSuite. We conducted content analysis using WordStat for each document separately. Each SDG target represented a category in the dictionary. To transform textual data into keywords or content categories, we used a lemmatization substitution process. Lemmatization is a "process by which various forms of words are reduced to a more limited number of canonical forms like conversion of plurals to singulars and past tense verbs to present tense verbs" [35].

For each occurrence identified by the software, an expert in charge of the processing validated the result to retain only relevant occurrences. These retained occurrences were then classified within a matrix where they were associated with corresponding targets. The matrix is based on the rapid integrated assessment developed by the United Nations Development Programme [33] (Table 1). 
Table 1. Excerpts of the matrix of links between the SDG targets (6.1 to 6.6) and the analyzed Quebec City strategic documents. The X mark indicates an occurrence between a strategic document and an SDG target (The full matrix is available in the Supplementary Materials). The title of each strategic document has been translated by the authors from the original French title.

\begin{tabular}{|c|c|c|c|c|c|c|c|c|}
\hline \multirow{2}{*}{ City Service } & \multirow{2}{*}{ Strategic Document } & \multicolumn{7}{|c|}{ SDG 6-Clean Water and Sanitation } \\
\hline & & 6.1 & 6.2 & 6.3 & 6.4 & 6.5 & 6.6 & Total \\
\hline $\begin{array}{l}\text { Water management/Provide a sustainable } \\
\text { and healthy environment/Stimulate the } \\
\text { development of the city }\end{array}$ & $\begin{array}{l}\text { Vision for the development of } \\
\text { agricultural and } \\
\text { food-processing activities }\end{array}$ & & & & & & & 0 \\
\hline Water management & $\begin{array}{l}\text { Summary of actions to protect } \\
\text { Lake St. Charles and water intake } \\
\text { Environmental and water }\end{array}$ & $\mathrm{x}$ & & $\mathrm{x}$ & $\mathrm{x}$ & & $\mathrm{x}$ & 4 \\
\hline Water management & $\begin{array}{l}\text { regulations of the Quebec } \\
\text { metropolitan community }\end{array}$ & $\mathrm{x}$ & & & & & $\mathrm{x}$ & 2 \\
\hline Water management & $\begin{array}{l}2018 \text { annual report on drinking } \\
\text { water quality }\end{array}$ & $\mathrm{x}$ & & $\mathrm{x}$ & & & & 2 \\
\hline Water management & $\begin{array}{l}\text { Drinking water regulations for } \\
\text { the Quebec City agglomeration }\end{array}$ & $x$ & & $x$ & $\mathrm{x}$ & & & 3 \\
\hline
\end{tabular}

We processed the data from the matrix to obtain a portrait of the SDG target coverage by the existing strategic documents and to group those documents influencing the same targets. Through identifying occurrences between the strategic documents and the SDG targets, we could assess, in light of the identified actions, the degree to which SDG targets had been achieved (performance). We assessed performance on a four-level scale:

1. The target was not at all achieved;

2. The target was partially achieved: there is much room for improvement, although some results are visible;

3. The target is in the process of being achieved: improvements remain possible;

4. The target has been achieved.

We automatically assigned a performance score of 1 to targets having no occurrences. We awarded a performance score of 2 or 3 when occurrences existed between the city's strategic documents and a target. Our assessment of performance varied in accordance with the number of strategic documents associated with a target and the quality of actions mentioned in those documents. We never assigned a maximum score of 4 , as we found no indicator, with verified metrics, for which we could attribute this performance.

\subsection{Identification of Synergies and Trade-Offs}

To apply systems thinking, we organized a workshop with the aim of identifying the potential interactions between the applied activities within the various city services. The research team identified themes for the 107 operational targets on the basis of target content and their indicators. SDG targets fall into two categories: "operational" and "means of implementation" (MoI). Operational targets relate to those to be achieved, whereas MoI refers to conditions that help attain targets [36]. MoI includes the mobilization of financial resources, technology development and transfer, capacity building, inclusive and equitable trade, regional integration, and the creation of a national environment conducive to the implementation of the sustainable development agenda [1]. MoI targets apply to national competences, which deviate from those at the local level. We therefore discarded MoI targets and SDG 17 [31,37].

As an initial step, the 27 leaders identified areas of activity undertaken both inside and outside of their administrative units and associated these areas with the themes of the SDG targets. Then, they identified potential interactions with other SDG targets. All interactions are directional; hence, for each interaction, there is a source target and an impacted target. In the case of bidirectional interactions, we used two-directional interactions, reversing sources and impact. City leaders characterized interactions as synergies or trade-offs. A 
member of the research team validated each of the interactions and completed the exercise by adding interactions and adjusting some interactions associated erroneously with targets. Once the validation was completed, we analyzed the synergies and trade-offs by SDG and target. We used a cross-impact matrix $[27,30,31,38]$ where the weight given to an interaction corresponds to the number of activities associated with the interaction.

\subsection{Importance and Prioritization}

Localizing the SDGs requires adapting the global reference framework to ensure that it is relevant to the local context [3,6]. This contextualization of the 2030 Agenda will promote ownership and mobilization of stakeholders [14,39]. To increase the understanding of the SDGs and their targets for the stakeholders in our study, we adapted the wording of the targets without changing the original meaning. The target labels were adjusted to change references from a national scale to a local scale. For example, Target 1.2: "By 2030, reduce at least by half the proportion of men, women and children of all ages living in poverty in all its dimensions according to national definitions" becomes "By 2030, reduce at least by half the proportion of men, women and children of all ages living in poverty in all its dimensions according to the city definitions."

Targets adapted to the local context were prioritized during a workshop that brought together 182 city employees. The employees occupied positions at various levels throughout the city services. We sampled city employees to ensure the representativeness of employment sectors, age group, gender, and workplace location. The selected employees did not need any particular skills or knowledge to participate in the workshop. Prioritization is an essential stage in identifying the relevant actions to be implemented at the local level [4].

Twenty-four tables of seven to eight employees, separated across two three-hour sessions, discussed the level of importance of SDG targets in the context of Quebec City. The table composition was predetermined to maximize diversity. Each table weighted the targets of three to four SDGs, for a total of 21 to 22 targets per table. An animator facilitated the discussion, while a second person recorded notes on a prepared canvas. Each participant was provided access to a set of four cards, representing the four levels of importance, to help them judge the importance of a target:

N/A: Not applicable;

1: Unimportant: Not important and not a priority;

2: Important: Priority in the medium to long term;

3: Essential: Priority in the short term.

For each target, (1) the animator announced and explained the appropriate target; (2) the employees expressed their views on the level of importance to be given to the target; (3) the animator initiated a dialogue in regard to the employees' justifications for this importance; and (4) the employees then expressed their final scoring for the importance of the target after these discussions.

We recorded both employee assessments of importance (before and after discussions), and we noted the employees' justifications. To define the final level of importance of the targets to be entered in the SDGT-PG, we averaged (rounded to the nearest unit) the importance score of the final results.

Using the SDGT-PG, we produced a priority index for each target. The more participants that deemed a target to be significant and the poorer the target's performance, the greater the priority given to the target in question. The priority level corresponds to the table shown in Figure 2. 


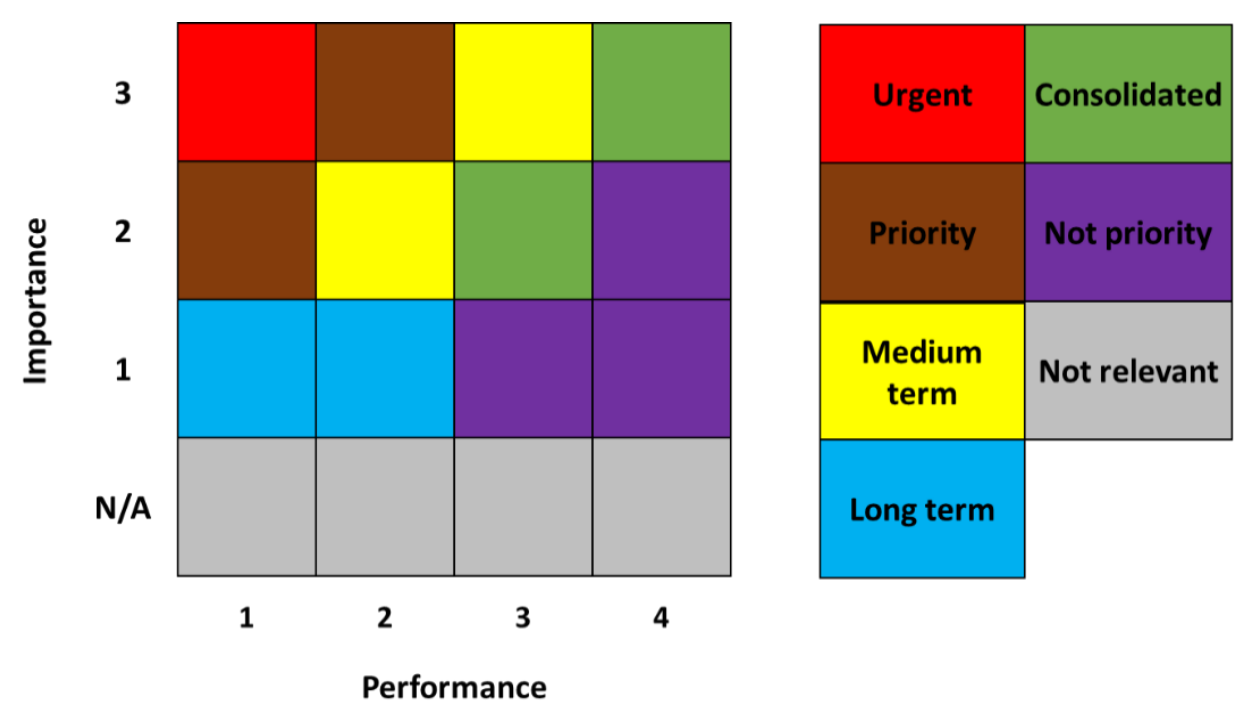

Figure 2. Prioritization index grid in which an urgent target requires immediate intervention: a priority target should be addressed within a three-year horizon, a medium-term target should be addressed within seven years, a long-term target should be addressed within a 10-to-15-year period, and a target to be consolidated requires interventions that make it possible to maintain the current level of performance. The other priority levels do not require specific actions.

\subsection{Governance}

This stage aims to determine, for each target, the level of governance, from local to national, legally responsible for implementing actions required to achieve the target. In our case, the national level includes both the provincial and federal governments. The project team evaluated the target with reference to legislation at the Quebec (provincial) and Canada (federal) levels. To identify the governance level, we classified governance on a scale from 1 to 4 :

1. Exclusive responsibility of the local level. The local level has complete authority to act on this target.

2. Responsibility shared between the local and national levels. The local level has a certain authority to act on this target; however, these competencies are also shared with the national level.

3. National-level responsibility supported by the local level. The national level has the main responsibilities necessary to act on this target; however, it can delegate to the local level for implementing an action. The local level has a certain authority for ensuring action on the ground, but it does not hold decision-making power.

4. Exclusive national-level responsibility. The national level has the full authority to act on this target. The local level does not have the authority to intervene, although it can sometimes influence priorities through representations at the national level.

\subsection{Localization}

The final information produced in the SDGT-PG considered the role of the different levels of governance in implementing initiatives; this governance level can affect whether a target can be achieved. Combining the priority level (Figure 2) and the governance assessment, we could determine what should be considered by local and national planners and what targets can be achieved jointly, in some form of multilevel governance (Table 2). 
Table 2. Initiatives to be undertaken according to the level of priority and our governance assessment. These are proposals aimed at local (Quebec City) and national (Quebec, Canada) levels.

\begin{tabular}{|c|c|c|c|c|c|}
\hline & \multicolumn{5}{|c|}{ Level of Governance } \\
\hline & & Local & Shared & $\begin{array}{l}\text { National Supported } \\
\text { by Local }\end{array}$ & National \\
\hline \multirow{2}{*}{ 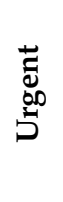 } & Local & $\begin{array}{l}\text { Implementation } \\
\text { of actions }\end{array}$ & $\begin{array}{l}\text { Implementation } \\
\text { of actions }\end{array}$ & Search for opportunities & $\begin{array}{l}\text { Advocacy at the } \\
\text { appropriate } \\
\text { governance level }\end{array}$ \\
\hline & National & $\begin{array}{l}\text { Financial, technical, } \\
\text { human support }\end{array}$ & $\begin{array}{l}\text { Financial, technical, } \\
\text { human support }\end{array}$ & $\begin{array}{l}\text { Actions considering } \\
\text { local characteristics }\end{array}$ & Implementation of actions \\
\hline \multirow{2}{*}{$\overbrace{\substack{0 \\
0}}^{2}$} & Local & $\begin{array}{l}\text { Implementation } \\
\text { of actions }\end{array}$ & $\begin{array}{l}\text { Implementation } \\
\text { of actions }\end{array}$ & Search for opportunities & Search for opportunities \\
\hline & National & $\begin{array}{c}\text { Direct support at the } \\
\text { local level }\end{array}$ & $\begin{array}{c}\text { Direct support at the } \\
\text { local level }\end{array}$ & $\begin{array}{l}\text { Actions considering } \\
\text { local characteristics }\end{array}$ & Implementation of actions \\
\hline \multirow{2}{*}{ 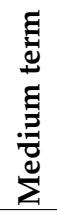 } & Local & $\begin{array}{l}\text { Implementation } \\
\text { of actions }\end{array}$ & $\begin{array}{l}\text { Implementation } \\
\text { of actions }\end{array}$ & None & None \\
\hline & National & $\begin{array}{l}\text { Financial, technical, } \\
\text { human support }\end{array}$ & $\begin{array}{l}\text { Direct support at the } \\
\text { local level }\end{array}$ & $\begin{array}{l}\text { Actions considering } \\
\text { local characteristics }\end{array}$ & Implementation of actions \\
\hline \multirow{2}{*}{ 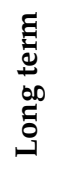 } & Local & Search for opportunities & Search for opportunities & None & None \\
\hline & National & $\begin{array}{l}\text { Financial, technical, } \\
\text { human support }\end{array}$ & Long-term planning & Long-term planning & Long-term planning \\
\hline \multirow{2}{*}{ 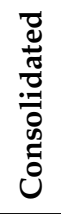 } & Local & $\begin{array}{l}\text { Consolidation of actions } \\
\text { already implemented }\end{array}$ & $\begin{array}{l}\text { Consolidation of actions } \\
\text { already implemented }\end{array}$ & $\begin{array}{l}\text { Consolidation of actions } \\
\text { already implemented }\end{array}$ & None \\
\hline & National & None & $\begin{array}{c}\text { Collaboration with the } \\
\text { local level }\end{array}$ & $\begin{array}{c}\text { Collaboration with the } \\
\text { local level }\end{array}$ & $\begin{array}{l}\text { Consolidation of actions } \\
\text { already implemented }\end{array}$ \\
\hline \multirow{2}{*}{ 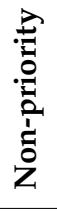 } & Local & $\begin{array}{l}\text { Consolidation of actions } \\
\text { already implemented }\end{array}$ & $\begin{array}{l}\text { Consolidation of actions } \\
\text { already implemented }\end{array}$ & $\begin{array}{l}\text { Consolidation of actions } \\
\text { already implemented }\end{array}$ & None \\
\hline & National & None & $\begin{array}{c}\text { Collaboration with the } \\
\text { local level }\end{array}$ & $\begin{array}{c}\text { Collaboration with the } \\
\text { local level }\end{array}$ & $\begin{array}{l}\text { Consolidation of actions } \\
\text { already implemented }\end{array}$ \\
\hline \multirow{2}{*}{ 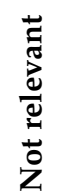 } & Local & None & None & None & None \\
\hline & National & None & None & None & None \\
\hline
\end{tabular}

\section{Results}

\subsection{Performance Assessment}

Our diagnosis aimed to assess the potential achievement of the SDG targets by identifying those already considered within the city strategic documents and by assessing the degree to which they had been achieved. We found that the city documents dealt with 85 targets, representing $50 \%$ of the total SDG targets (Table 3). We noted a difference in coverage between the operational targets (71\%) and the MoI (15\%). No document covered the targets of SDG 14; however, five SDGs had 100\% of their operational targets considered by at least one strategic document. 
Table 3. SDG and targets covered by the analyzed Quebec City strategic documents.

\begin{tabular}{|c|c|c|c|c|c|c|c|c|c|}
\hline SDG & $\begin{array}{c}\text { Results } \\
\text { Target } \\
(n)\end{array}$ & $\begin{array}{l}\text { Results Target } \\
\text { Covered } \\
(n)\end{array}$ & $\begin{array}{c}\text { Results } \\
\text { Target } \\
\text { Covered (\%) }\end{array}$ & $\begin{array}{l}\text { MoI } \\
\text { Targets } \\
\text { (n) }\end{array}$ & $\begin{array}{l}\text { MoI Targets } \\
\text { Covered } \\
(n)\end{array}$ & $\begin{array}{l}\text { MoI Targets } \\
\text { Covered (\%) }\end{array}$ & $\begin{array}{l}\text { Total } \\
\text { Targets } \\
\text { (n) }\end{array}$ & $\begin{array}{c}\text { Total } \\
\text { Targets } \\
\text { Covered }(n)\end{array}$ & $\begin{array}{l}\text { Total Targets } \\
\text { Covered } \\
(\%)\end{array}$ \\
\hline 1 & 5 & 4 & 80 & 2 & 0 & 0 & 7 & 4 & 57 \\
\hline 2 & 5 & 2 & 40 & 3 & 0 & 0 & 8 & 2 & 25 \\
\hline 3 & 9 & 5 & 56 & 4 & 1 & 25 & 13 & 6 & 46 \\
\hline 4 & 7 & 4 & 57 & 3 & 1 & 33 & 10 & 5 & 50 \\
\hline 5 & 6 & 4 & 67 & 3 & 0 & 0 & 9 & 4 & 44 \\
\hline 6 & 6 & 6 & 100 & 2 & 0 & 0 & 8 & 6 & 75 \\
\hline 7 & 3 & 3 & 100 & 2 & 0 & 0 & 5 & 3 & 60 \\
\hline 8 & 10 & 9 & 90 & 2 & 0 & 0 & 12 & 9 & 75 \\
\hline 9 & 5 & 5 & 100 & 3 & 0 & 0 & 8 & 5 & 63 \\
\hline 10 & 7 & 6 & 86 & 3 & 0 & 0 & 10 & 6 & 60 \\
\hline 11 & 7 & 7 & 100 & 3 & 1 & 33 & 10 & 8 & 80 \\
\hline 12 & 8 & 6 & 75 & 3 & 1 & 33 & 11 & 7 & 64 \\
\hline 13 & 3 & 3 & 100 & 2 & 0 & 0 & 5 & 3 & 60 \\
\hline 14 & 7 & 0 & 0 & 3 & 0 & 0 & 10 & 0 & 0 \\
\hline 15 & 9 & 6 & 67 & 3 & 1 & 33 & 12 & 7 & 58 \\
\hline 16 & 10 & 6 & 60 & 2 & 1 & 50 & 12 & 7 & 58 \\
\hline 17 & $x$ & $x$ & $x$ & 19 & 3 & 16 & 19 & 3 & 16 \\
\hline Total & 107 & 76 & 71 & 62 & 9 & 15 & 169 & 85 & 50 \\
\hline
\end{tabular}

Note: SDG 1: No poverty; SDG 2: Zero hunger; SDG 3: Good health and well-being; SDG 4: Quality education; SDG 5: Gender equality; SDG 6: Clean water and sanitation; SDG 7: Affordable and clean energy; SDG 8: Decent work and economic growth; SDG 9: Industry, innovation and infrastructure; SDG 10: Reduced inequalities; SDG 11: Sustainable cities and communities; SDG 12: Responsible consumption and production; SDG 13: Climate action; SDG 14: Life below water; SDG 15: Life on land; SDG 16: Peace, justice, and strong institutions; SDG 17: Partnerships for the goals.

Table 3 illustrates that 84 targets (50\%) are not covered, including $53 \mathrm{MoI}$ targets (of a possible 62). SDG targets are also unequally covered by the strategic documents (Figure 3). Dividing the analyzed documents into blocks of five (for clarity's sake in Figure 3), we noted that 46 targets were represented only within 1 to 5 documents, 15 targets were found in 6 to 10 documents, 12 targets were covered by 11 to 15 documents, only 4 targets were found in 16 to 20 documents, and 8 targets were linked to 20 or more documents. Thus, most documents covered only a limited number of SDG targets.

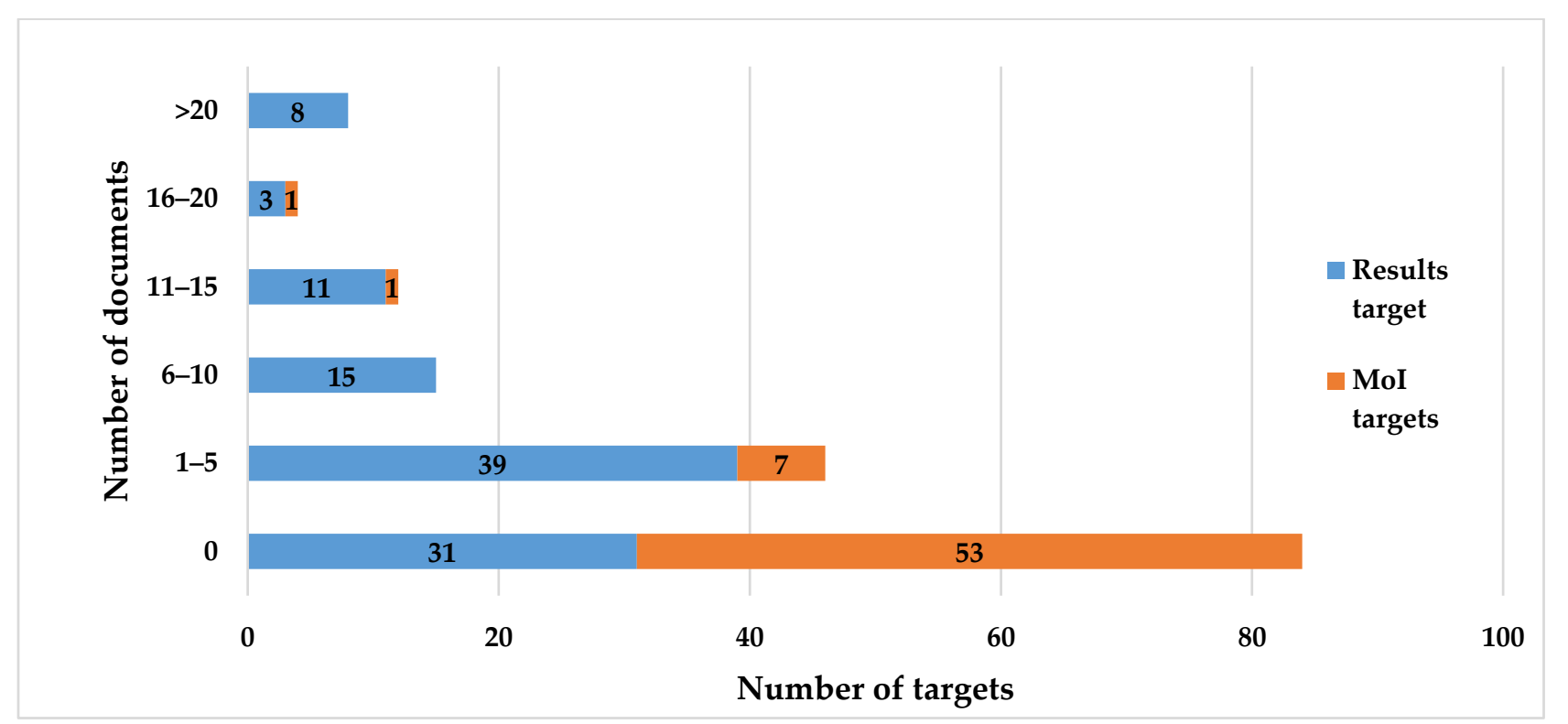

Figure 3. Number of targets covered by the strategic documents.

Of the eight most covered targets, three come from SDG 11 (Sustainable cities and communities), two from SDG 9 (Industry, innovation, and infrastructure) and SDG 16 (Peace, justice, and strong institutions), and one from SDG 3 (Good health and well-being). 
We used the potential coverage of SDG targets to assess performances in the SDGT-PG. Except for SDG 2 and 14, at least $60 \%$ of the targets showed some performance in terms of potentially achieving the target (Figure 4). No target could be labeled as "achieved" because we found no indicators confirming this level of performance. Targets of SDG 6 (Clean water and sanitation) and 11 (Sustainable cities and communities) showed more than $80 \%$ of the targets had a performance ranking of 3 "in the process of being achieved" (Figure 4).

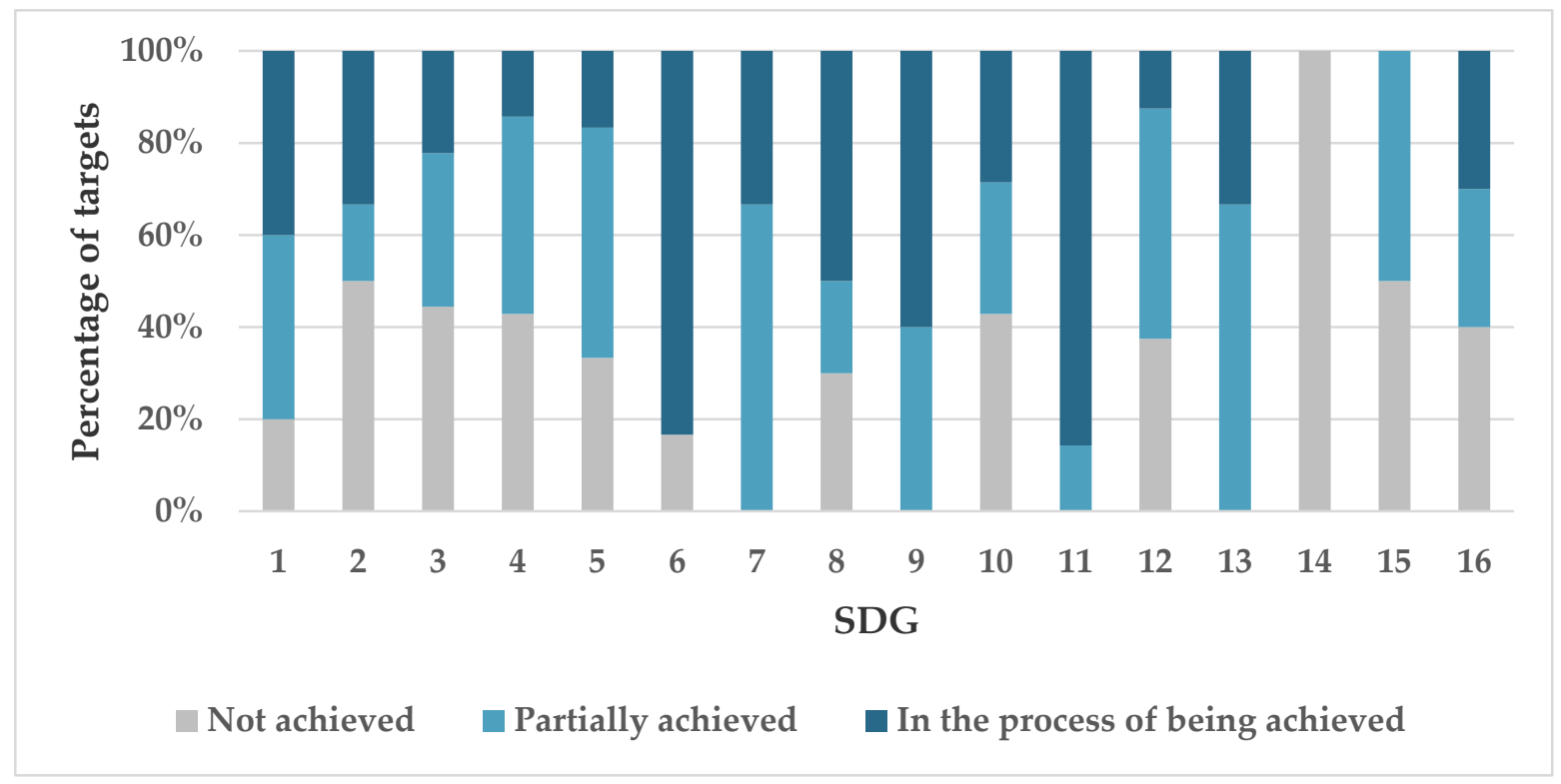

Figure 4. Distribution of the performance of the SDG targets found within the 89 Quebec City strategic documents.

\subsection{Synergies and Trade-Offs}

The city officers and our research team identified 687 potential interactions, including 638 synergies and 49 trade-offs. These interactions involve 86 targets and 16 SDGs. Table 4 shows the targets that most influenced other targets on the basis of the number of times they are the source of interaction. The table also reveals the targets most influenced by other targets according to the number of times they are impacted by other targets. All these targets exhibited positive and negative interactions. Among all the analyzed interactions, the most influencing and most influenced targets were all strongly positive (Table 4).

Table 4. Most influencing and most influenced targets. Numbers in parentheses identify the number of positive/negative interactions, respectively, in which the targets are involved. (The full crossimpact matrix is available in the Supplementary Materials).

\begin{tabular}{|c|c|}
\hline Most Influencing Targets & Most Influenced Targets \\
\hline $\begin{array}{l}\text { 9.5-Scientific research, technological } \\
\text { capabilities, and innovation }(50 / 4)\end{array}$ & $\begin{array}{l}\text { 3.4-Non-communicable disease, mental health, } \\
\text { well-being }(54 / 2)\end{array}$ \\
\hline 7.3-Energy efficiency $(41 / 4)$ & $\begin{array}{l}\text { 10.2-Empowerment; social, economic, and } \\
\text { political inclusion }(45 / 5)\end{array}$ \\
\hline $\begin{array}{l}\text { 11.3-Sustainable urbanization, participatory } \\
\text { planning and management }(42 / 3)\end{array}$ & $\begin{array}{l}\text { 15.1-Terrestrial and inland freshwater } \\
\text { ecosystems }(25 / 4)\end{array}$ \\
\hline $\begin{array}{l}\text { 9.4-Upgrade infrastructure; resource-use } \\
\text { efficiency; clean technologies and industrial } \\
\text { processes }(26 / 4)\end{array}$ & $\begin{array}{l}\text { 11.6-Environmental impact of cities; air quality; } \\
\text { waste management }(23 / 1)\end{array}$ \\
\hline $\begin{array}{l}\text { 10.2-Empowerment; social, economic, and } \\
\text { political inclusion }(28 / 2)\end{array}$ & 2.1-Hunger; nutritious and sufficient food $(20 / 3)$ \\
\hline $\begin{array}{l}\text { 12.8-Information and awareness for } \\
\text { sustainable development }(29 / 1)\end{array}$ & 13.2-Climate change measures $(20 / 1)$ \\
\hline
\end{tabular}


Influencing targets came from various SDGs. The exception was SDG 9, for which two targets were found in the five most influencing targets (Table 4). In the context of applying the SDGs at the municipal level, we expected and noted Target 11.3 (Sustainable urbanization; participatory and integrated planning and management) to be one of the most (the third) influential targets (Table 4).

The most impacted targets came from six SDGs. The most impacted target is 3.4 (Non-communicable diseases, mental health, and well-being). We found a single target (10.2. Empowerment; social, economic, and political inclusion) in both the most influencing and the most influenced targets (Table 4).

The targets included in Table 4 have the highest positive results. In terms of negative impacts, targets 7.3, 9.4, 9.5, and 15.1 most negatively affected other targets (sum: -4 ). The most often negatively impacted targets were targets 8.1 (sum: -7 ) and 10.2 (sum: -5 ). The highest positive interaction was between targets 11.3 and 10.2 (sum: 5). We observed the highest negative results (sum: -2 ) for interactions between targets 9.4 and 3.4, between 9.5 and 10.3, and between 15.1 and 11.1.

At the SDG level, targets from SDG 9 (sum: 100) and SDG 11 (sum: 99) had the highest positive net influence on other targets (Figure 5). Targets SDG 3 (sum: 76), SDG 11 (sum: 69), SDG 8 (sum: 53), SDG 10 (sum: 52), and SDG 12 (sum: 51) were most often impacted by other targets, according to their net influence. We noted that $94.7 \%$ of net influence was positive when excluding absent relationships. The greatest net-positive influence was from SDG 11 toward SDG 10 (sum: 23). The net influence of SDG 15 toward SDG 8 was the most negative (sum: -3 ) (Figure 5).

\begin{tabular}{|c|c|c|c|c|c|c|c|c|c|c|c|c|c|c|c|c|c|}
\hline & $\begin{array}{l}\vec{u} \\
\text { के }\end{array}$ & $\begin{array}{l}N \\
\text { ஸे } \\
\text { Oे }\end{array}$ & $\begin{array}{l}m \\
0 \\
\text { के }\end{array}$ & $\begin{array}{l}\text { H } \\
\text { क }\end{array}$ & $\begin{array}{l}n \\
0 \\
\text { ஸे }\end{array}$ & $\begin{array}{l}0 \\
0 \\
0\end{array}$ & $\begin{array}{l}\hat{U} \\
\text { के }\end{array}$ & $\begin{array}{l}\infty \\
0 \\
\infty\end{array}$ & $\begin{array}{l}\hat{0} \\
\hat{\omega}\end{array}$ & 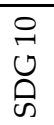 & $\begin{array}{l}\overrightarrow{7} \\
\text { U } \\
\text { के }\end{array}$ & 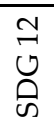 & $\begin{array}{l}\stackrel{m}{1} \\
\text { के }\end{array}$ & $\begin{array}{l}\text { J } \\
\text { U } \\
\text { की }\end{array}$ & 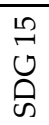 & 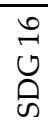 & 志 \\
\hline SDG 1 & & 3 & 5 & 2 & 6 & & & 1 & -1 & 7 & 3 & & & & 1 & & 27 \\
\hline SDG 2 & 3 & 2 & 3 & & & & & -1 & & -1 & -1 & 2 & & & 1 & & 8 \\
\hline SDG 3 & & & & & 2 & & & & & & & & & & & & 2 \\
\hline SDG 4 & 4 & 2 & 3 & 1 & 9 & 3 & 1 & 7 & & 8 & 3 & 3 & 1 & & & 3 & 48 \\
\hline SDG 5 & 2 & 2 & 4 & & & & & 2 & & 1 & 1 & & & & & 1 & 13 \\
\hline SDG 6 & 2 & & 12 & & & 6 & & 3 & & & 1 & 1 & 2 & 1 & 7 & & 35 \\
\hline SDG 7 & 3 & 3 & 4 & -1 & & 1 & 1 & 7 & 3 & 1 & 7 & 6 & 7 & & & & 42 \\
\hline SDG 8 & & 3 & 3 & & 2 & & & & & 4 & 4 & 4 & 4 & & 4 & & 28 \\
\hline SDG 9 & 3 & 1 & 2 & 4 & 1 & 6 & 9 & 12 & 6 & 2 & 19 & 15 & 8 & 1 & 9 & 2 & 100 \\
\hline SDG 10 & 4 & 5 & 5 & 2 & 9 & 1 & & 3 & & & 5 & & 1 & & & 4 & 39 \\
\hline SDG 11 & 3 & 3 & 16 & 3 & 4 & 1 & 2 & 7 & 3 & 23 & 11 & 7 & 5 & & 4 & 7 & 99 \\
\hline SDG 12 & 1 & 4 & 8 & 2 & 1 & 7 & 4 & 12 & 3 & -1 & 7 & 8 & 7 & & 4 & & 67 \\
\hline SDG 13 & & & 3 & & & & 2 & 2 & 2 & 1 & 2 & 3 & & & & & 15 \\
\hline SDG 14 & & & & & & & & & & & & & & & & & 0 \\
\hline SDG 15 & 1 & & 8 & & & 6 & & -3 & 1 & 1 & 5 & 1 & 3 & 2 & 12 & & 37 \\
\hline SDG 16 & 1 & & & 5 & 5 & & & 1 & 1 & 6 & 2 & 1 & 1 & & & 6 & 29 \\
\hline Sum & 27 & 28 & 76 & 18 & 39 & 31 & 19 & 53 & 18 & 52 & 69 & 51 & 39 & 4 & 42 & 23 & \\
\hline
\end{tabular}

Figure 5. Cross-impact matrix of 16 SDGs. Numbers indicate the net influence of positive and negative interactions between targets of the corresponding SDGs.

\subsection{Importance, Prioritization, and Governance}

The participants at the prioritization workshop assessed the level of importance of the 107 operational targets (Figure 6). They found all targets to be relevant. The participants considered most targets as important $(56.1 \%)$, with 32 targets deemed essential $(29.9 \%)$ and 15 as unimportant $(14 \%)$. The SDGs having the highest percentage of essential targets were 
SDG 6 (66.7\%) and SDGs 5, 12, and 16 (50\%) (Figure 5). SDGs 3 and 14 had the highest percentage of unimportant targets ( $44.4 \%$ and $57.1 \%$, respectively).

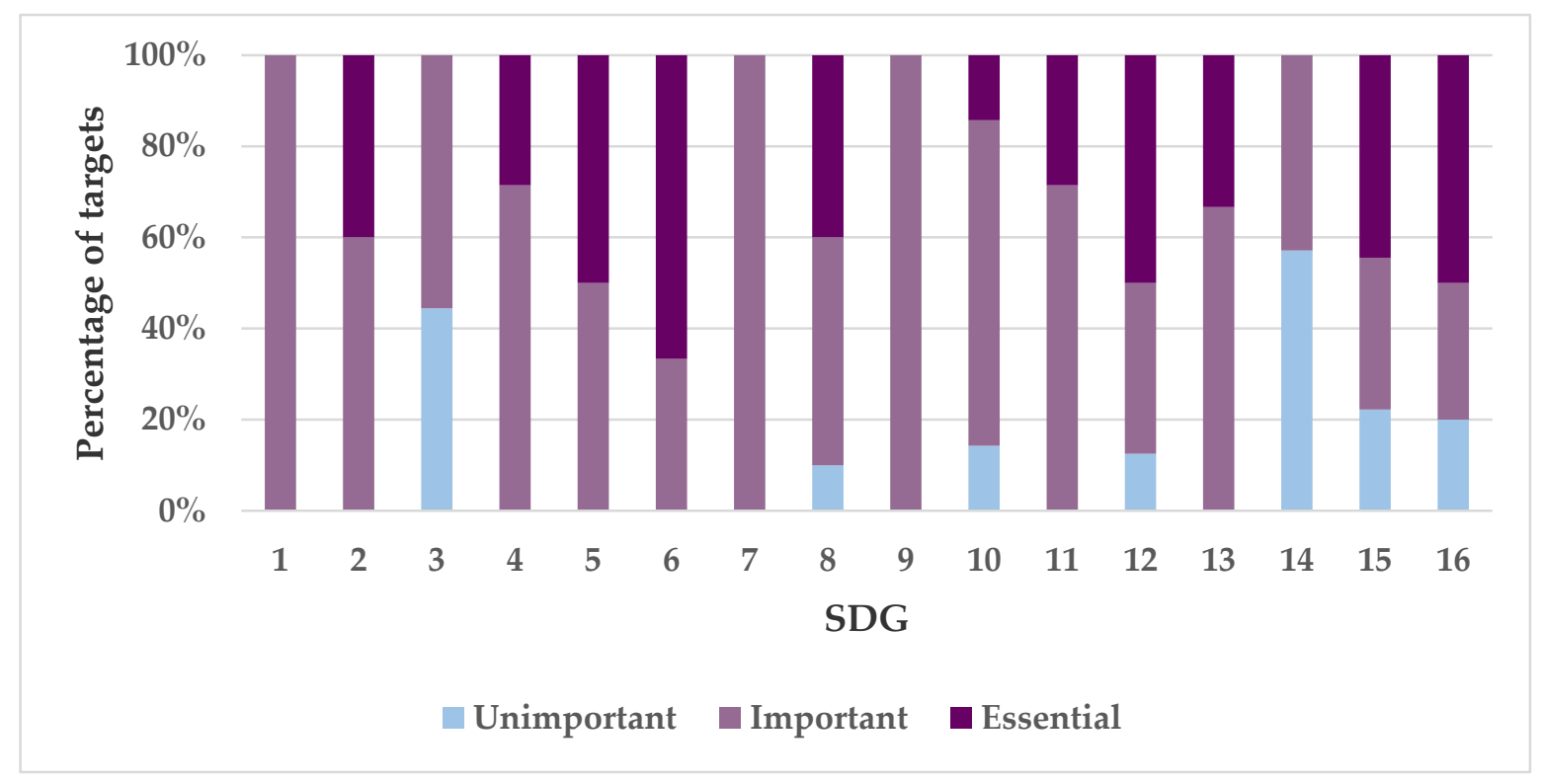

Figure 6. Distribution of the level of importance given to the SDG targets by the Quebec City round tables.

We obtained a prioritization index by crossing performance with importance. Eight targets, among eight different SDGs, were prioritized as urgent (Figure 7), whereas 27 targets were deemed a priority. We noted five priority targets in SDG 15, four in SDG 12, three each in SDGs 4, 14, and 16, two each in SDGs 2, 5, and 8, and one each in SDG 1, 10, and 13. SDGs 3, 7, 9, and 11 did not have any urgent or priority targets (Figure 6). Thirty-four targets were prioritized in the medium term and fifteen in the long term. Additionally, Quebec City needed to consolidate 23 targets. SDG 11, with four targets, and SDG 8 and 9, each with three targets, showed the most targets to be consolidated.

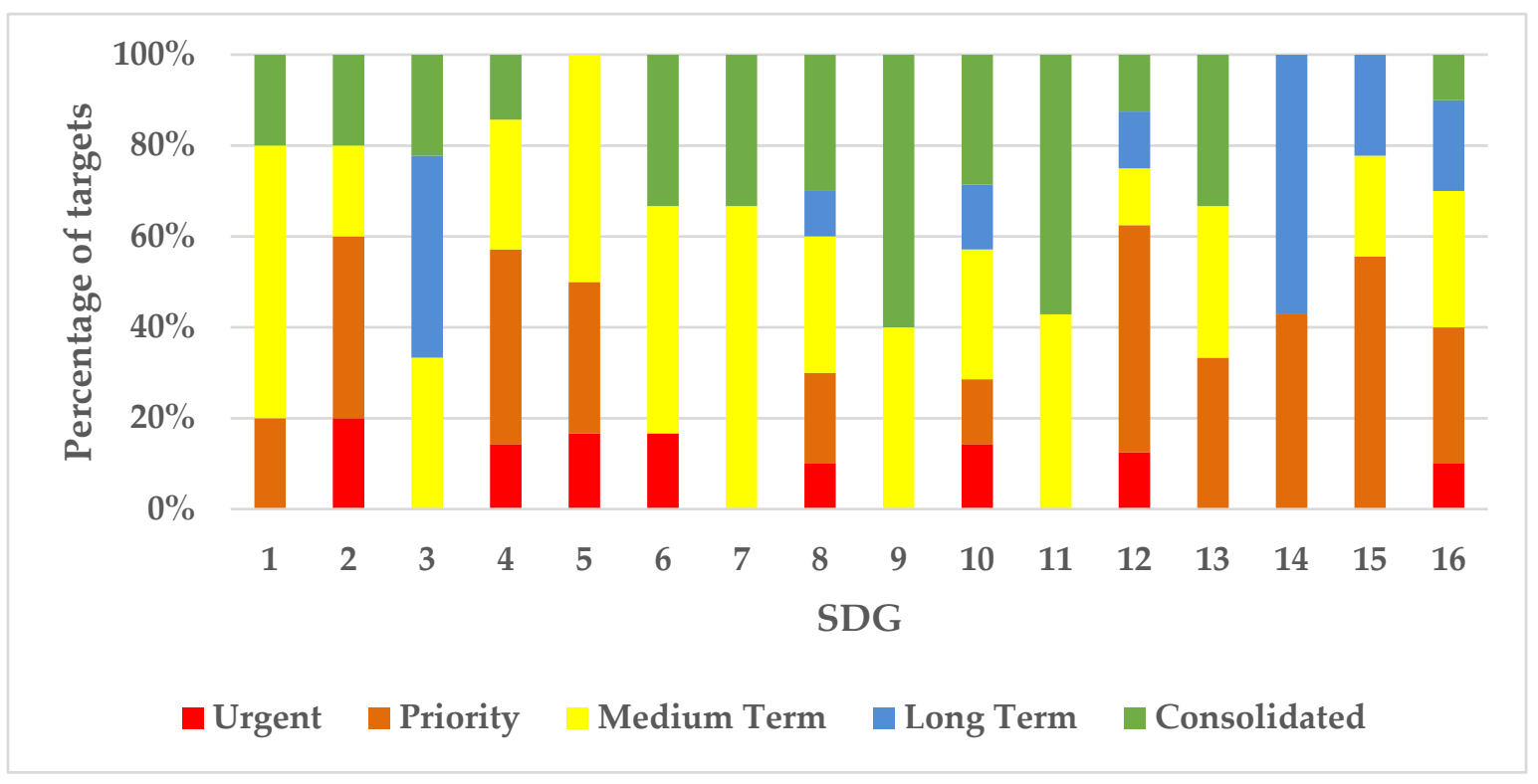

Figure 7. Prioritization levels for each SDG. (A detailed table including all targets is available under the "detailed results" tab of the SDGT-PG available in the Supplementary Materials). 
The governance assessment showed that the project team members considered Quebec City to have exclusive power over six targets (5.6\%) (Figure 8). These targets are found in SDGs 6, 11, and 12 (each having two targets). On the other hand, they assessed 29 targets $(27.1 \%)$ as being exclusively national (provincial or federal) jurisdiction and responsibility. Among the SDG targets most associated with the national level, we noted five of the seven targets of SDG $14(71 \%)$, two of the three targets of SDG $7(67 \%)$, and four of the seven targets of SDG 4 and $10(57 \%)$. Twenty-six targets (24.3\%) represented a shared responsibility, and 46 targets $(43 \%)$ were primarily national competence, although supported at the local level. Overall, the national level was better positioned to intervene on 75 targets $(70 \%)$; for instance, the national level holds most of the authority to intervene in regard to all targets of SDGs 4 and 7 (Figure 7).

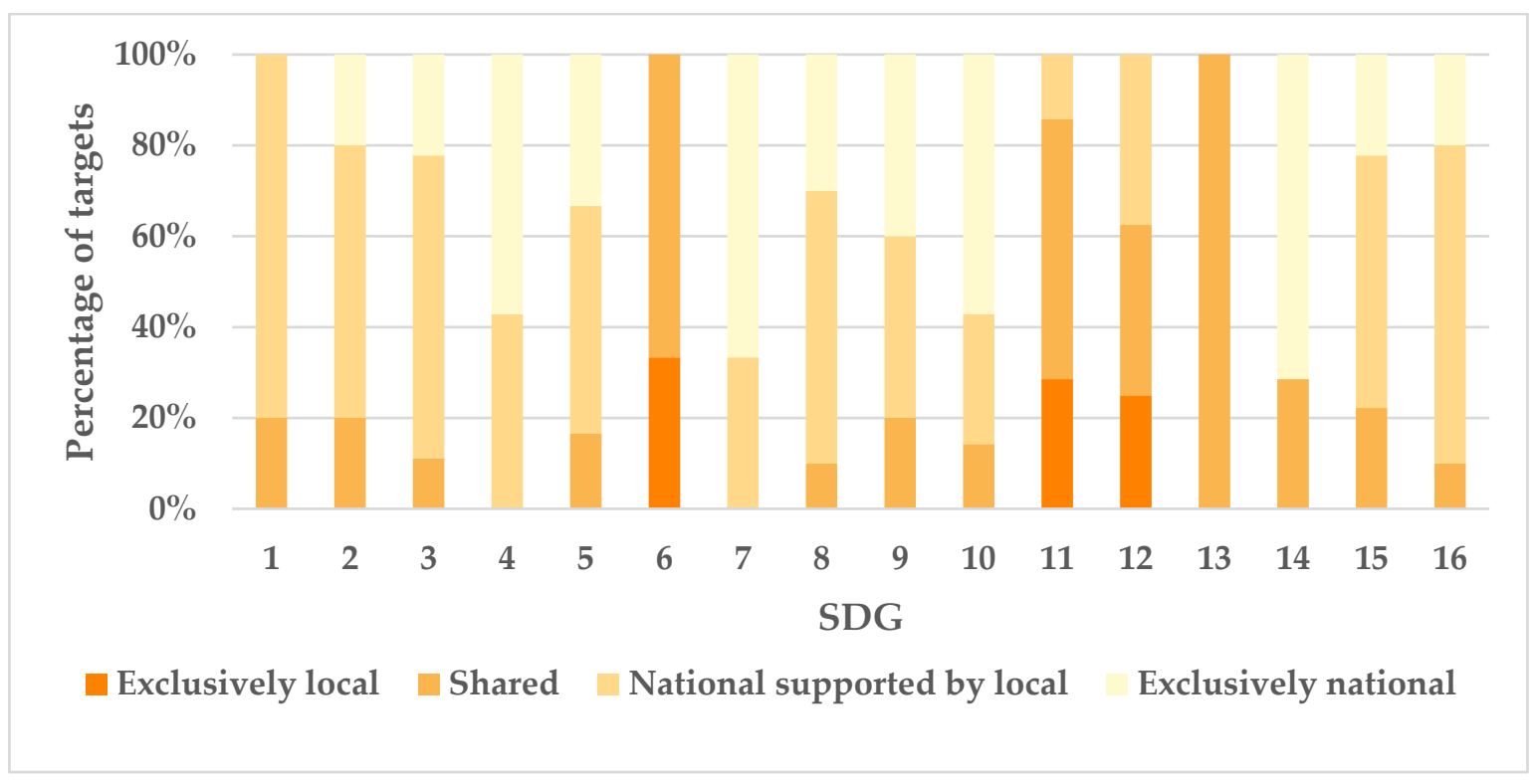

Figure 8. Distribution of the SDG targets among the levels of governance.

\section{Discussion}

The success of implementing the 2030 Agenda requires the mobilization of all actors at all levels. Our SDG localization approach focuses on the local level and includes an original systemic tool to identify priorities in a context of strategic planning. We used parameters found in the literature $[6,20,30]$; they were evaluated separately but integrated to define the priorities.

In our study case, assessing the current sustainability context for Quebec City is necessary to clarify the starting point and to develop a sustainable development strategy based on achievements [14]. The development and application of our dictionary of expressions linked to the SDG targets identified the targets considered (or not) within the city's strategic documents.

A proper analysis of performance requires contextualizing performance in terms of governance level. Local governments, depending on the effective distribution of powers in a given country, have varying levers on the SDGs. Quebec City is located in the province of Quebec and also falls within the Canadian national governance. The responsibility for municipalities resides with the provinces under the Canadian constitution. In the province of Quebec, cities have the legislative powers of development and urban planning, housing, roads, community and cultural development, recreation, urban public transport, and wastewater treatment [40]. We strongly recommend that an expert assessment of governance parameters, in accordance with the national/provincial legislative texts, be undertaken when applying an SDGT-PG. 
Examining the distribution of powers among government levels allows an analysis of performance crossed with an evaluation of governance (Table 5). In this study, we observed that no exclusively local responsibility target was achieved. Among the exclusively national targets (at the provincial and/or federal level), however, $69 \%$ of the targets had not been achieved. In Canada, navigation, coasts, and inland fisheries are a federal responsibility. Five of the seven SDG 14 targets related to oceans and marine resources are exclusively a national responsibility and have not yet been achieved. The two other targets are considered as a shared responsibility. In contrast, Quebec City was on track to achieve $83 \%$ of the targets under its responsibility. These are targets of SDG 6 (Clean water and sanitation) and 11 (Sustainable cities and communities), which correspond to the fields of competence given to municipalities in provincial legislation. The other targets of exclusive local responsibility were partially achieved.

Table 5. Distribution related to the performance and level of governance.

\begin{tabular}{|c|c|c|c|c|c|}
\hline & Exclusively Local & $\begin{array}{c}\text { Shared } \\
\text { Responsibility }\end{array}$ & $\begin{array}{c}\text { National } \\
\text { Supported by Local }\end{array}$ & $\begin{array}{c}\text { Exclusively } \\
\text { National }\end{array}$ & \\
\hline \multirow{4}{*}{$\begin{array}{c}\text { The target is not achieved at all } \\
\text { The target is partially achieved } \\
\text { The target is in the process of } \\
\text { being achieved }\end{array}$} & $0 \% / 0 \%$ & $23 \% / 16.2 \%$ & $23.9 \% / 29.7 \%$ & $69 \% / 54 \%$ & $100 \%$ \\
\hline & $16.7 \% / 2.8 \%$ & $23 \% / 16.7 \%$ & $50 \% / 63.9 \%$ & $20.7 \% / 16.7 \%$ & $100 \%$ \\
\hline & $83.3 \% / 14.7 \%$ & $53.9 \% / 41.2 \%$ & $26.1 \% / 35.3 \%$ & $10.3 \% / 8.8 \%$ & $100 \%$ \\
\hline & $100 \%$ & $100 \%$ & $100 \%$ & $100 \%$ & \\
\hline
\end{tabular}

Note: For the pairs of percentage values, the percentage in bold represents the relative distribution of target performance related to the governance level, whereas the percentage presented in normal font represents the relative distribution of the targets' level of governance related to the performance.

Agenda 2030 states that the SDGs and their targets are global and that [national] governments should define their priorities according to their particular contexts [1]. This contextualization applies to all levels of governance, from local to national. The successful implementation of SDGs requires multilevel governance implemented with communication channels that promote vertical integration $[7,41]$. Although cities have extremely varied contexts, they encounter common obstacles, such as issues of power [24], and can seize specific opportunities addressed by our approach. Moreover, localization allows local authorities to participate more effectively to achieve national SDGs.

\subsection{Obstacles, Limitations, and Challenges of SDG Localization}

The scope of the 2030 Agenda limits its localization. The formulation of targets is addressed at the national and global levels, and their text-based interpretation can have a demobilizing effect on the local-level actors. Local actors may see this agenda as being focused on global issues and, thus, they may ultimately reject the agenda outright [42] Implementing SDGs at the local level requires localizing the targets by adjusting the labels without distorting their meaning. In our case study, the Quebec City project team modified the wording of targets, for which the scope was explicitly national, to provide a local-scale feel to the target. This adaptation increases the tangibility of targets for local actors, who must assess the importance of the targets and ensure that the targets are implemented at the appropriate-local-level. One could assume that targets explicitly mentioning a national scope would be assessed as less important or not applicable for local actors. For the MoI targets, however, adapting these targets to local contexts is difficult, as these targets often involve international partnerships for implementing the 2030 Agenda. From the governance parameter of the SDGT-PG, responsibility for the MoI targets occurs exclusively at the national level. For the sake of adaptation and contextualization, and not to give the impression to local actors that the 2030 Agenda is addressed only at the national level, we chose to exclude the MoI targets from our prioritization approach.

Localizing the SDGs involves implementing the SDGs in the logic of vertical, horizontal, and territorial integration. A siloed approach predominates, and moving toward an integrated approach is not straightforward. 
Forming a group of leaders from different municipal services promoted horizontal integration. The leaders were not used to working in a multiservice group. Their collective work and dialogue broke down existing silos. The multiservice workshops greatly helped identify potential synergies and trade-offs. This horizontal integration occurred at several stages of our approach. During the diagnosis stage, our analysis of strategic documents, using the dictionary of expressions related to the SDG targets, identified the initial potential synergies. For example, we identified that the following targets touched all services: 4.4 (Skills for employment and entrepreneurship), 8.2 (Economic productivity), 9.1 (Sustainable infrastructure, economic development, well-being), 9.5 (Research, technological capabilities, innovation), 16.6 (Efficient, accountable, and transparent institutions), and 16.7 (Participation in decision-making). These shared targets do not systematically imply synergistic actions, but the diagnosis identified those actions carried out by several municipal services sharing common objectives. Our dictionary has proven to be a highly relevant and effective tool for undertaking this diagnosis.

The identification of 687 potential interactions formalized the links between city services and contributed to horizontal integration. The in-depth analysis and articulation of interactions illustrated the integrated nature of the actions of all services to members of the leader group. We observed that $92.8 \%$ of the interactions were positive by nature. This result closely matches the systemic analysis applied to the case of Sweden by Weitz et al. [31], where $96 \%$ of interactions were synergies. Referring to the classification of SDG targets to the five pillars of the 2030 Agenda (population, planet, prosperity, peace, and partnership) in Tremblay et al. [15], we observed that $83 \%$ of positive interactions (sum of +2 and greater) were linked to the same pillars. Half of the negative interactions related to different pillars. This illustrates the complexity of SDG targets and their interactions, and how the different pillars are integrated and indivisible.

The limits and challenges of vertical and territorial integration are multiple and complex. These types of integration refer to the principle of subsidiarity, "the search for the 'optimal scale of government,' [28] and the concept of multilevel governance, a system of continuous negotiation among nested governments at several territorial tiers" [43]. These limits and challenges are universal but vary depending on the context. Thus, there is not a single solution, but it is possible to provide adaptable reflections from our approach.

The actors of governance, at different scales, have variable levels of control and power over their context. This control varies from none (e.g., distribution of natural resources across the territory) to full (e.g., the adoption of policies). In addition, the actors interact according to different paradigms, at their level, in a complex system where the dominant paradigm of economic neoliberalism is omnipresent and, sometimes, underground [44-47]. It is well known that states tend to protect their powers despite the recognized importance of applying the principle of subsidiarity for implementing sustainable development [11].

The application of the principle of subsidiarity is linked directly to power issues, a very sensitive subject [24]. Local governments, to respond effectively to their sustainability challenges, must have the corresponding powers. From this perspective, Jones [48] writes, "Where national and state/provincial governments fail to act, city governments are severely limited in the implementation of [sustainability] policy." To address these issues, governments must collaborate. Using the governance assessment in the SDGT-PG, we guided local governments on the types of actions available to them on the basis of their specific governance context and target priority while also proposing actions at the national level. The terms "Search for opportunities" and "Advocacy at the appropriate governance level" apply to targets having a high priority level (urgent or priority) and whose governance is at the national level. This intersection between three parameters of the SDGT-PG helps guide the advocacy that local governments must undertake at higher levels. This observation does not guarantee success and an openness to dialogue; however, it provides guidelines for a structured argument based on an inclusive approach. The aim is to reduce what the OECD identified as the "policy gap" [49]. To achieve this, we 
must establish mechanisms for collaborating between the levels of governance to make the implementation of public policies relevant and effective.

Localizing the SDGs requires an integrated commitment of human and financial resources [3]. SDSN [6] observed that, despite the importance of localizing SDGs, questions regarding capacities and mobilizing resources remain unanswered. Thus, the major constraints that cities face relate primarily to their limited political and fiscal powers, their lack of access to finance, the low levels of institutional capacity, the lack of multilevel government cooperation and integration, and the difficulty in establishing multi-stakeholder partnerships [6]. Becoming aware of these constraints is, however, a necessary step. Cities can act directly on a few aspects of sustainability, but they need the collaboration and openness of higher levels of governance to tackle the ensemble of issues. Open and empowered multilevel governance is essential for localizing SDGs horizontally, vertically, and territorially within an integrated approach [50].

\subsection{Opportunities}

The 2030 Agenda is mobilizing an enormous quantity of resources across the globe, and actors at all levels are developing appropriate tools and approaches. The number of scientific articles having "2030 Agenda" as a keyword has increased rapidly from 44 in 2015 to 246 in 2017 to 632 in 2020 (Scopus, search results using "2030 Agenda" as a keyword, 5 November 2020). The SDGs and their targets provide a relevant framework at all scales and are internationally recognized. The principle of integration is increasingly applied, and organizations (national, local, private) increasingly choose the SDG framework for the sake of multilevel consistency.

This willingness to join the SDG movement must be supported politically. In Quebec City, the mayor undertook the process, leading to a strategy and an action plan for sustainable development. This engagement at the highest levels of local government is essential for committing all necessary resources to ensure the success of the process [48]. Thus, the mayor's office established a competent project team that mobilized stakeholders, coordinated and analyzed activities, and developed the necessary strategy. Furthermore, a team of leaders, mobilized within all of the city's administrative units-because of the support of the directors of the various units mobilized by the mayor's office-has been trained in sustainable development issues. The team members communicated the progression of the approach and raised awareness with their colleagues. They sought their views at various stages of the process [48,51,52]. This multiservice mobilization was achieved through the mayor's commitment, through a top-down approach, to provide the means for achieving the results. The presence of a city councilor of the executive committee at every stage of the process testified to this political will. Mobilization at the highest level facilitates awareness of the efforts and actions to be implemented to vertically integrate the process. In our case study, Quebec City does not hold all the necessary powers to respond to the priorities that emerged from the prioritization exercise. City officers will be obliged to develop partnerships with higher governance bodies. As the mayor is the process holder in this case study, he will feel all the more invested and convinced of the need to carry out this task and to use the right communication channels to develop a multilevel collaboration. However, it is important to reiterate that the mobilization of the mayor alone cannot guarantee a successful implementation of sustainable development. It is also essential for all stakeholders to rally and face the challenges related to sustainability.

Cities must build on existing structures and actions already underway that fit within the sustainability framework to ensure optimal localization of the SDGs [14]. Our diagnosis provides a relatively rapid portrait of the situation, an exercise that can often be tedious. In our case study, we included the diagnosis at the stage of evaluating the performance parameter of the SDGT-PG. The use of the dictionary made it possible to undertake rigorous work with a minimum mobilization of human resources. It provided a solid starting point on which to build the remainder of the process and made it possible to identify a common starting point for all actors involved. 
Crises can constitute opportunities to introduce a sustainability approach. Some previous crises (climate, financial, energy, etc.) have been drivers of change. For example, the 2008 financial crisis motivated some countries to embark on a transition movement $[53,54]$. The COVID-19 pandemic may also turn out to be an opportunity to provide arguments that favor the implementation of a sustainable development strategy. Quebec City, as most other local and national governments, must implement a post-containment/COVID-19 recovery strategy. This recovery strategy, linked to a sustainable development strategy, could offer an opportunity to facilitate ownership of the shift and the actions proposed by the city. In terms of sustainability, however, not all crises become opportunities. As stated in the 2030 Agenda: "There can be no sustainable development without peace and no peace without sustainable development" [1]. Thus, crises such as armed conflicts remain major obstacles to sustainability.

Local governance is the closest level of government to citizens and their issues. This reality allows, in theory, to quickly implement measures to respond effectively to identified problems. The local level involves fewer actors and fewer divergent issues than at the national level. This difference could explain why differing from "business as usual" can be easier to implement at the local level [55]. For example, in the context of local actions, actors are less influenced by the dominant paradigm of neoliberalism and thus allows the emergence of approaches considered more radical when compared with "business as usual" actions $[47,55,56]$. Cities should support grassroots initiatives [42] and socio-ecological transition projects [57] undertaken by local community groups in their territories. These partnerships are much easier to support by local governments that are in direct contact with these groups. Leadership at the top of the city hierarchy (top-down) and support of bottom-up initiatives are not contradictory and mutually reinforce each other [24]. In this sense, Quebec City has opened a dialogue with local partners from various civil society organizations with the objective of identifying challenges, issues, and opportunities, as well as proposals for action.

The identified limitations and opportunities routinely brought us back to the need for multilevel governance to ensure implementation of the 2030 Agenda [7,11]. The national level of governance, although holding most of the powers (Figure 7), must be aware that the national level is not always the most appropriate level in regard to local actors and issues [28]. The motivation of local governments can be hampered by the lack of collaboration of higher governance bodies [42]. The evaluation of the governance parameters shows higher authorities must collaborate with local governments. As Meuleman and Niestroy state [24], the issues and contexts differ at all levels, and a lack of integration and collaboration can lead to failure. A multilevel governance approach that relies on collaboration and cooperation will help promote vertical integration and policy coherence [50]. Our analyses identified targets representing opportunities to build such collaborations, allowing local and national authorities to optimize their contributions for achieving the goals of the 2030 Agenda.

\section{Conclusions}

Our approach aligns with the best practices for localizing SDGs and includes the concepts of contextualization, localization, systems approach, and integration. Although we apply this approach to the local level, it is flexible and adjustable enough to be applied at all levels of governance. Our approach provides a procedure that empowers sustainability actors in line with vertical and horizontal integration through capacity building, awareness, and direct participation, a procedure that, to our knowledge, has not been provided in previous studies focused on the local level.

Each application of our approach should be contextualized, as the opportunities and limitations differ from place to place. In our case, we were limited by a lack of data; the indicators of the SDG targets had yet to be assessed. Therefore, it was impossible to accurately assess performance. We stated that they were potential performances, and we remain conservative in our assessments by not describing any targets as being fully achieved. 
The systemic tools and approach presented in our study will help planners develop strategies and action plans for implementing the 2030 Agenda. Although our approach is complete, it can only be implemented with a mobilization at the highest level and with the involvement of stakeholders who represent the complexity of the system in which the agenda is being implemented. SDG localization faces other challenges, in particular the adaptation of SDG tools and approaches to the private sector, where each particular sector comprises its challenges, contexts, opportunities and specific scopes of organizations governance. Future research could help define, as in the present study, good practices in localizing the SDGs, and methodologies for adapting the 2030 Agenda to the private sector.

Supplementary Materials: The following are available online at https:/ / www.mdpi.com/2071-105 0/13/5/2520/s1, Table S1: List of analyzed documents, Table S2: Dictionary linked to the content of the 2030 Agenda, Table S3: Matrix of links between SDG targets and the analyzed Quebec City strategic documents inspired by the Rapid integrated assessment (RIA), Table S4: Cross-impact matrix, Table S5: Sustainable development goal target prioritization grid of Quebec City.

Author Contributions: Conceptualization, D.T., C.V., and S.G.; SDGT-PG methodology, O.R., D.T., and C.V.; WordStat, D.T.; Validation, D.T., J.-F.B., O.R., S.D., S.G., and C.V.; Formal analysis, D.T., S.G., and S.D.; Writing-original draft preparation, D.T.; Supervision, J.-F.B. and C.V.; Project administration, C.V. All authors commented all the sections and reviewed the manuscript. All authors have read and agreed to the published version of the manuscript.

Funding: This research received no external funding.

Institutional Review Board Statement: Not applicable.

Informed Consent Statement: Not applicable.

Data Availability Statement: Data is contained within the article or Supplementary Material.

Acknowledgments: The authors acknowledge the contribution of the project team and the group of city leaders. The authors thank the project director, Yohan Maubrun, for his leadership and openness. The authors acknowledge the support of the Organisation Internationale de la Francophonie and its subsidiary body, l'Institut de la Francophonie pour le Développement Durable, for their support in the development of systemic sustainability analysis tools since 2012. The lead author thanks the Université du Québec à Chicoutimi and the Chaire en éco-conseil de l'Université du Québec à Chicoutimi for their financial support. We also thank Murray Hay of Maxafeau Editing Services.

Conflicts of Interest: The authors declare no conflict of interest.

\section{References}

1. United Nations. Transforming Our World: The 2030 Agenda for Sustainable Development; Resolution Adopted by the General Assembly on 25 September 2015. (A/RES/70/1). 2015. Available online: http://www.un.org/ga/search/view_doc.asp?symbol= $\mathrm{A} / \mathrm{RES} / 70 / 1 \&$ Lang=E (accessed on 8 December 2016).

2. Allen, C.; Reid, M.; Thwaites, J.; Glover, R.; Kestin, T. Assessing national progress and priorities for the Sustainable Development Goals (SDGs): Experience from Australia. Sustain. Sci. 2020, 15, 521-538. [CrossRef]

3. Krellenberg, K.; Bergsträßer, H.; Bykova, D.; Kress, N.; Tyndall, K. Urban sustainability strategies guided by the SDGs-A tale of four cities. Sustainability 2019, 11, 1116. [CrossRef]

4. Zinkernagel, R.; Evans, J.; Neij, L. Applying the SDGs to cities: Business as usual or a new dawn? Sustainability 2018, 10, 3201. [CrossRef]

5. United Nations Development Programme. A Multi-Dimensional Focus for the 2030 Agenda; United Nations Development Programme: New York, NY, USA, 2017; p. 14.

6. Kanuri, C.; Revi, A.; Espey, J.; Kuhle, H. Getting Started with the SDGs in Cities: A Guide for Stakeholders; Sustainable Development Solutions Network: New York, NY, USA, 2016; p. 110.

7. Graute, U. Local Authorities Acting Globally for Sustainable Development. Reg. Stud. 2016, 50, 1931-1942. [CrossRef]

8. Kharrazi, A.; Qin, H.; Zhang, Y. Urban big data and sustainable development goals: Challenges and opportunities. Sustainability 2016, 8, 1293. [CrossRef]

9. Klopp, J.M.; Petretta, D.L. The urban sustainable development goal: Indicators, complexity and the politics of measuring cities. Cities 2017, 63, 92-97. [CrossRef]

10. United Nations; Department of Economic and Social Affairs; Population Division. World Urbanization Prospects: The 2018 Revision; United Nations: New York, NY, USA, 2019; p. 126. 
11. Fenton, P.; Gustafsson, S. Moving from high-level words to local action-Governance for urban sustainability in municipalities. Curr. Opin. Environ. Sustain. 2017, 26-27, 129-133. [CrossRef]

12. Hoornweg, D.; Hosseini, M.; Kennedy, C.; Behdadi, A. An urban approach to planetary boundaries. Ambio 2016, 45, 567-580. [CrossRef] [PubMed]

13. Parnell, S. Defining a Global Urban Development Agenda. World Dev. 2016, 78, 529-540. [CrossRef]

14. Gustafsson, S.; Ivner, J. Implementing the Global Sustainable Goals (SDGs) into Municipal Strategies Applying an Integrated Approach. In Handbook of Sustainability Science and Research; Leal Filho, W., Ed.; Springer International Publishing: Cham, Switzerland, 2018; pp. 301-316. [CrossRef]

15. Tremblay, D.; Fortier, F.; Boucher, J.-F.; Riffon, O.; Villeneuve, C. Sustainable development goal interactions: An analysis based on the five pillars of the 2030 agenda. Sustain. Dev. 2020, 28, 1584-1596. [CrossRef]

16. United Nations Development Programme; UN-Habitat; GTF of Local and Regional Governments. Localizing the Post-2015 Development Agenda- Dialogues on Implementation; United Nations: New York, NY, USA, 2015.

17. Riffon, $\mathrm{O}$. Une typologie pour l'analyse des représentations du développement durable des instruments de mise en oeuvre à l'échelle territoriale. In Les Instruments de L'action Publique et les Dispositifs Territoriaux; L'Harmattan: Paris, France, 2016; pp. 43-58.

18. Barnett, C.; Parnell, S. Ideas, implementation and indicators: Epistemologies of the post-2015 urban agenda. Environ. Urb. 2016, 28, 87-98. [CrossRef]

19. Bibri, S.E.; Krogstie, J. Smart sustainable cities of the future: An extensive interdisciplinary literature review. Sustain. Cities Soc. 2017, 31, 183-212. [CrossRef]

20. Osborn, D.; Cutter, A.; Ullah, F. Universal Sustainable Development Goals_Understanding the Transformational Challenge for Developed Countries; Stakeholder Forum: London, UK, 2015; p. 25.

21. Hamdouch, A.; Depret, M.-H. Sustainable development policies and the geographical landscape of the green economy. Actors, scales and strategies. Finisterra Revista Portuguesa de Geografia 2012, 47, 49-80. [CrossRef]

22. Villeneuve, C.; Tremblay, D.; Côté, H.; Bonfils, S.; Prescott, J. La Gouvernance du Développement Durable Dans la Francophonie; Institut de l'énergie et de l'environnement de la Francophonie: Québec, QC, Canada, 2012.

23. Nilsson, M.; Chisholm, E.; Griggs, D.; Howden-Chapman, P.; McCollum, D.; Messerli, P.; Neumann, B.; Stevance, A.-S.; Visbeck, M.; Stafford-Smith, M. Mapping interactions between the sustainable development goals: Lessons learned and ways forward. Sustain. Sci. 2018, 13, 1489-1503. [CrossRef] [PubMed]

24. Meuleman, L.; Niestroy, I. Common But Differentiated Governance: A Metagovernance Approach to Make the SDGs Work. Sustainability 2015, 7, 12295-12321. [CrossRef]

25. Finnveden, G.; Gunnarsson-Östling, U. Sustainable development goals for cities. In Connecting the Dots by Obstacles? Friction and Traction Ahead of SRIA Urban Transitions Pathways; Bylund, J., Ed.; JPI Urban Europe: Brussels, Belgium, 2016.

26. Hansson, S.; Arfvidsson, H.; Simon, D. Governance for sustainable urban development: The double function of SDG indicators. Area Dev. Policy 2019, 4, 217-235. [CrossRef]

27. Nilsson, M.; Griggs, D.; Visbeck, M. Map the Interactions between Sustainable Development Goals. Nature 2016, 534, 320-322. [CrossRef] [PubMed]

28. Piattoni, S. Multi-level Governance: A Historical and Conceptual Analysis. J. Eur. Integr. 2009, 31, 163-180. [CrossRef]

29. Rivera, M. Political Criteria for Sustainable Development Goal (SDG) Selection and the Role of the Urban Dimension. Sustainability 2013, 5, 5034-5051. [CrossRef]

30. Allen, C.; Metternicht, G.; Wiedmann, T. Prioritising SDG targets: Assessing baselines, gaps and interlinkages. Sustain. Sci. 2019, 14, 421-438. [CrossRef]

31. Weitz, N.; Carlsen, H.; Nilsson, M.; Skånberg, K. Towards systemic and contextual priority setting for implementing the 2030 Agenda. Sustain. Sci. 2018, 13, 531-548. [CrossRef] [PubMed]

32. Villeneuve, C.; Tremblay, D.; Riffon, O.; Lanmafankpotin, G.; Bouchard, S. A Systemic Tool and Process for Sustainability Assessment. Sustainability 2017, 9, 1909. [CrossRef]

33. United Nations Development Programme. Rapid Integrated Assessment (RIA)_To facilitate Mainstreaming of SDGs into National and Local Plans; United Nations Development Programme: New York, NY, USA, 2017; p. 93.

34. Provalis Research. WordStat; Provalis Research: Montreal, QC, Canada, 2019.

35. Provalis Research. WordStat 7-User's Guide; Provalis Research: Montreal, QC, Canada, 2015; p. 199.

36. Lucas, P.L.; Kok, M.T.J.; Nilsson, M.; Alkemade, R. Integrating Biodiversity and Ecosystem Services in the Post-2015 Development Agenda: Goal Structure, Target Areas and Means of Implementation. Sustainability 2014, 6, 193-216. [CrossRef]

37. Le Blanc, D. Towards Integration at Last? The Sustainable Development Goals as a Network of Targets. Sustain. Dev. 2015. [CrossRef]

38. International Council for Science. A Guide to SDG Interactions: From Science to Implementation; International Council for Science: Paris, France, 2017; p. 239.

39. Weitz, N.; Persson, A.; Nilsson, M.; Tenggren, S. Sustainable Development Goals for Sweden: Insights on Setting a National Agenda; Stockholm Environment Institute: Stockholm, UK, 2015; p. 57. 
40. Ministère des Affaires Municipales et de L'HABITATION. Régime Municipal Général. Available online: https://www.mamh.gouv. qc.ca/organisation-municipale/organisation-territoriale/organisation-territoriale-municipale/regime-municipal-general/\#: $\sim\{\}:$ text=Les $\%$ 20responsabilit\%C3\%A9s\%20de\%20la\%20municipalit\%C3\%A9, assainissement \%20des\%20eaux\%20us\%C3\%A9 es\%2C\%20etc (accessed on 16 October 2020).

41. United Nations Development Program; Office of the High Commissioner for Human Rights. Global Thematic Consultation on Governance and the Post-2015 Development Framework - Consultation Report; UNDP and OHCHR: New York, NY, USA, 2013.

42. Lo, K. Urban carbon governance and the transition toward low-carbon urbanism: Review of a global phenomenon. Carbon Manag. 2014, 5, 269-283. [CrossRef]

43. Marks, G. Structural policy and multilevel governance in the EC. In The state of the European Community; Lynne Riener: Boulder, CO, USA, 1993; pp. 391-410.

44. Boehnert, J. The Green Economy: Reconceptualizing the Natural Commons as Natural Capital. Environ. Commun. J. Nat. Cult. 2016, 10, 395-417. [CrossRef]

45. Brand, U. Green Economy-The Next Oxymoron?: No Lessons Learned from Failures of Implementing Sustainable Development. Gaia 2012, 21, 28-32. [CrossRef]

46. Kosoy, N.; Brown, P.G.; Bosselmann, K.; Duraiappah, A.; Mackey, B.; Martinez-Alier, J.; Rogers, D.; Thomson, R. Pillars for a flourishing Earth: Planetary boundaries, economic growth delusion and green economy. Curr. Opin. Environ. Sustain. 2012, 4, 74-79. [CrossRef]

47. Wanner, T. The New 'Passive Revolution' of the Green Economy and Growth Discourse: Maintaining the 'Sustainable Development' of Neoliberal Capitalism. New Political Econ. 2015, 20, 21-41. [CrossRef]

48. Jones, S. Climate Change Policies of City Governments in Federal Systems: An Analysis of Vancouver, Melbourne and New York City. Reg. Stud. 2013, 47, 974-992. [CrossRef]

49. Charbit, C.; Michalun, M. Mind the gaps: Managng Mutual Dependence in Relations among Levels of Government; OECD: Paris, France, 2009; p. 189.

50. Corfee-Morlot, J.; Kamal-Chaoui, L.; Donovan, M.G.; Cochran, I.; Robert, A.; Teasdale, P.-J. Cities, Climate Change and Multilevel Governance; OECD: Paris, France, 2009; p. 125.

51. Betsill, M.M. Mitigating Climate Change in US Cities: Opportunities and obstacles. Local Environ. 2001, 6, 393-406. [CrossRef]

52. Burch, S. In pursuit of resilient, low carbon communities: An examination of barriers to action in three Canadian cities. Energy Policy 2010, 38, 7575-7585. [CrossRef]

53. Li, J.L.; Lin, B.Q. Green Economy Performance and Green Productivity Growth in China's Cities: Measures and Policy Implication. Sustainability 2016, 8, 947. [CrossRef]

54. Mathews, J.A. Green growth strategies-Korean initiatives. Futures 2012, 44, 761-769. [CrossRef]

55. Loiseau, E.; Saikku, L.; Antikainen, R.; Droste, N.; Hansjürgens, B.; Pitkänen, K.; Leskinen, P.; Kuikman, P.; Thomsen, M. Green economy and related concepts: An overview. J. Clean. Prod. 2016, 139, 361-371. [CrossRef]

56. Hobson, K. 'Weak' or 'Strong' Sustainable Consumption? Efficiency, Degrowth, and the 10 Year Framework of Programmes. Environ. Plan. C Gov. Policy 2013, 31, 1082-1098. [CrossRef]

57. Audet, R.; Segers, I.; Manon, M. Expérimenter la transition écologique dans les ruelles de Montréal: Le cas du projet Nos milieux de vie! Lien social et Politiques 2019, 224-245. [CrossRef] 